\title{
Estimation of crop water requirement for rice- wheat and rice- maize cropping system using CROPWAT model for Pusa, Samastipur district, Bihar
}

\author{
RAVISH CHANDRA $^{1 *}$ AND SHABANAM KUMARI ${ }^{2}$
}

\begin{abstract}
This study is about estimation of crop water requirement for rice-wheat and rice-rabi maize cropping system for Pusa Region of Samastipur district of Bihar using CROPWAT model for year 2017-18.The effective rainfall was calculated using USDA S.C. Method. Reference crop evaporation was calculated using meteorological data viz temperature, relative humidity, wind speed and Sunshine using Penman Monteith equation. The meteorological data were collected from university observatory of R.P.C.A.U Pusa. Crop coefficient $(\mathrm{Kc})$ value was taken according to crop growth stages. Effective rainfall and crop water requirement was used for determining net irrigation requirement. The annual crop water requirement of Rice- Wheat cropping system was found to be $904.1 \mathrm{~mm}$ whereas the crop-water requirement of Rice- Rabi Maize cropping system was $991.7 \mathrm{~mm}$.
\end{abstract}

KEYWORDS

CROPWAT, Crop coefficient, Crop evapotranspiration, Crop water requirement

\begin{tabular}{lcc}
\multicolumn{3}{c}{ ARTICLE INFO } \\
\hline Received on & $:$ & $27 / 03 / 21$ \\
Accepted on & $:$ & $24 / 06 / 21$ \\
Published online & $:$ & $30 / 06 / 21$ \\
\hline
\end{tabular}

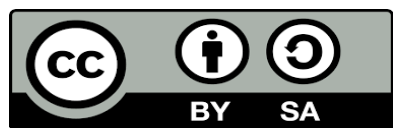

\section{INTRODUCTION}

$\mathrm{W}$ ater is the most vital input of agriculture. Water has a very important role in soil and plant growth. Agriculture is the largest user of water resources and accounts for around $80 \%$ of all water abstraction. Among the various sources of irrigation water, groundwater plays an important role in irrigated agriculture in India, contributing about $60 \%$ of the net cultivated area (Shah et al, 2006) Increasing physical water scarcity would further affect food security. in recent years, the concept of water productivity in agriculture has gained ground as productivity changes from land to water productivity. Due to the increasing scarcity of irrigation water productivity. The main objective of cropping system is to obtain the higher agricultural return on the one hand and to maintain the soil fertility on the other. In other word, crop rotation helps in making agriculture more sustainable (Ali, 2010). The water requirement of different cropping system for different regions needs to be worked out. CROPWAT is a decision support system developed by the Land and Water Development Division of FAO (Fao, 2014). CROPWAT is a tool to carry out standard calculation for reference evapotranspiration, crop water requirement and crop irrigation requirement (Vk and Choudhary 2015 and Smith1992) This model really helps irrigation engineers to analyze the uses of crop water of an irrigation system. It can also be used to assess farmers' irrigation practices and estimate crop yields in both rainy and irrigated conditions. CROPWAT allows the user to enter measured ETo values or enter data on temperature, relative humidity, wind speed and hours of sunshine so that CROPWAT can calculate ETo using the Penmen Monteith equation (Jeet et al, 2016). The RiceWheat and Rice-Maize are the predominant cropping system of Bihar. The irrigation water is the key for increasing the productivity of Rice-Wheat and Rice-Maize cropping system (; Kumari et al., 2019) (Kumar et al, 2018). Therefore, estimation of crop water requirement and Irrigation Scheduling for Rice-Wheat and Rice-Rabi Maize is very important in the context of Bihar. Keeping the importance of irrigation water in Rice-Wheat and Rice-Rabi Maize cropping system, the crop water requirement and irrigation scheduling for Rice-Wheat and Rice-Rabi Maize cropping system was estimated for Pusa Region of Samastipur district using CROPWAT model.

\section{MATERIAL AND METHODS}

\section{Study Area}

The study area is located at Pusa block of Samastipur of North Bihar. It is surrounded by southern and western bank of the river Burhi Gandak at $25.98^{0} \mathrm{~N}$ latitude, $85.67^{\circ} \mathrm{S}$ longitudes and at about $59.92 \mathrm{~m}$ above mean sea level (Figure 1 ). The annual rainfall in the area is about $1270 \mathrm{~mm}$, out of which $1026 \mathrm{~mm}$ is received during monsoon month (JulySeptember). The average minimum and maximum temperatures during the hottest months of the May to June go up to $43-44^{\circ} \mathrm{C}$, respectively. The soil was calcareous, characterized by the presence of 26.6 calcium carbonate. The Pusa region consists of sandy loam with sand $(57 \%)$, silt $(31 \%)$ and clay (12\%). The average Bulk density was $1.63 \mathrm{~g} / \mathrm{cm} 3$.

\footnotetext{
1 Assistant Professor (SWE), Dr. Rajendra Prasad Central Agricultural University, Pusa, Samastipur, Bihar, India

2 Research Scholar, Deptt. of Processing and Food Engg., Odisha University of Agriculture \& Technology, Bhubaneswar, Odisha

${ }^{*}$ Corresponding author email: ravish.cae@gmail.com
} 


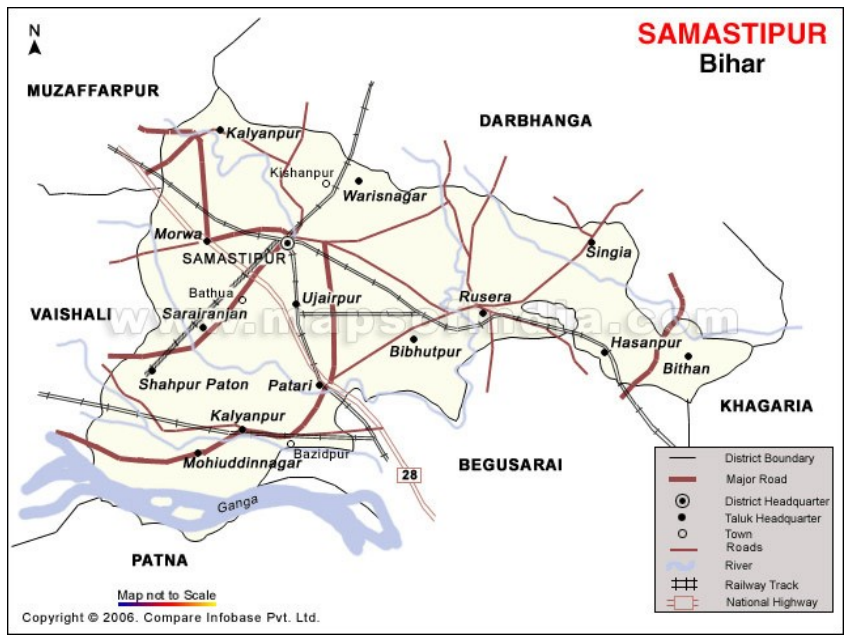

Fig. 1: Locationof Study Area (Source: www.krishi.bih.nic.in )

\section{CROPWAT Model}

CROPWAT 8.0 is a free software for calculating the water demand of plants based on soil, climate and plant data (Doorenbos and Pruitt, 1977). In addition, the program enables the development of irrigation plans for different management conditions and the calculation of the supply system of the different cultivation patterns. CROPWAT 8.0 can also be used to assess farmers' irrigation practices and estimate crop yield in both rain-based cultivation and irrigated conditions. All calculation methods in CROPWAT 8.0 are based on the two FAO publications in the Irrigation and Drainage series, namely number 56"Crop evapotranspiration: Guidelines for calculating culture water requirements" and number 33with the title "Yield response to water". To execute a simulation of CROPWAT model, it is necessary to have sets of data: climate data, rain data, crop data, soil data and irrigation criteria. Climatic condition determines evapotranspiration computed by Penman Monteith formula, which is implemented in CROPWAT.

The FAO procedures for reference crop evapotranspiration and crop water requirements and CROPWAT program incorporate sallow the simulation of crop water use under various climate, crop and soil conditions. The meteorological

\section{RESULT AND DISCUSSION}

\section{Reference Evapotranspiration}

Crop water requirement was estimated using CROPWAT software, which is based on Penman-Monteith Method. The crop water requirement was estimated for Rice-Wheat and Rice-Rabi Maize cropping system. For estimating the crop water requirement, firstly reference evapotranspiration was calculated with the help of climatic data. Penman-Monteith parameters used to calculate ETo were latitude, longitude and altitude of the station, maximum and minimum temperature $\left({ }^{\circ} \mathrm{C}\right)$, maximum and minimum relative humidity $(\%)$, wind speed ( $\mathrm{km} /$ day) and hours of sunshine. The properties of the soil taken into account for the estimation of the water requirement of the cultivated plants are the content of available water $(\mathrm{mm} / \mathrm{m})$ and the depth of the soil $(\mathrm{cm})$.

The Penman-Monteith equation was adopted to calculate reference crop evapotranspiration due to it accurate output by using different meteorological variables in the study area. In order to compute the crop water requirement (CWR), crop coefficient $(\mathrm{Kc})$ values for the, rice, wheat and maize crop were obtained and multiplied with the reference evapotranspiration.

\section{Calculation of Crop Evapotranspiration}

The Penman-Monteith Method was used to determine the Reference Evapotranspiration $\left(\mathrm{ET}_{0}\right)$ using the equation (1). ETo $=\frac{0.408 \triangle(R n-G)+\gamma(900 / T+273) u 2(e s-e a)}{\Delta+\gamma(1+0.34 u 2)}$

- - - (1)

Where,

ETo represents the reference crop evapotranspiration (mm/ day);

$\mathrm{Rn}$ represents net radiation on the crop surface in $\left(\mathrm{MJ} / \mathrm{m}^{2}\right.$ day)

Represents soil heat flux density (MJ/ m2- day ;

$\mathrm{T}$, the average air temperature per day at a height of $2 \mathrm{~m}\left({ }^{0} \mathrm{C}\right)$; $\mathrm{u}_{2}$, the speed of wind at a height of $2 \mathrm{~m}$ in $\mathrm{m} / \mathrm{s}$;

es, the vapour pressure at saturation $(\mathrm{kPa})$;

ea. the actual vapour pressure;

es - ea., the saturation vapour pressure deficit $(\mathrm{kPa})$;

$\Delta$, slope vapour pressure curve $\left(\mathrm{kPa}^{0} \mathrm{C}\right)$ and

$\gamma$, the psychometric constant $\left(\mathrm{kPa}\left({ }^{0} \mathrm{C}\right)\right)$

The Penman-Monteith equation was adopted to calculate reference crop evapotranspiration due to it accurate output by using different meteorological variables in the study area.

The reference evapotranspiration $\left(\mathrm{ET}_{O}\right)$ is multiplied by the crop coefficient $(\mathrm{Kc})$ to obtain crop Evapotranspiration (Etc.), as shown in Equation (2).

$\mathrm{ETc}=\mathrm{Kc} \times \mathrm{ET}_{O}(2)$

The different crop parameter values adopted for rice, wheat and maize are presented in Table 1 respectively.

Method was used for calculation of reference evapotranspiration. Table 2 depicts total reference evapotranspiration during different months for Pusa region. The highest reference evapotranspiration was found in the month of May with a value of $5.49 \mathrm{~mm} /$ day. Whereas the lowest reference evapotranspiration was found in the month of January with a value of 1.26 $\mathrm{mm} /$ day. 
Table 1: Crop parameters adopted for Rice, wheat and Rabi Maize crop in year 2017-18

\begin{tabular}{|c|c|c|c|c|c|c|}
\hline Parameter & Nursery (30) & Land preparation (25) & Initial (25) & Development (35) & Mid-season (30) & Late (30) \\
\hline \multicolumn{7}{|l|}{ Rice } \\
\hline $\mathrm{K}_{C}$ wet & 1.2 & 1.05 & 1.10 & 1.20 & 1.20 & 1.05 \\
\hline Rooting depth (m) & - & - & 0.1 & - & 0.6 & - \\
\hline Puddling depth (m) & - & 0.4 & - & - & - & - \\
\hline Critical depletion & 0.2 & - & 0.2 & - & 0.2 & 0.2 \\
\hline Yield response factor & - & - & 1.0 & 1.09 & 1.32 & 0.5 \\
\hline Crop height (m) & - & - & - & - & 1.0 & - \\
\hline Wheat & - & - & Initial (40) & Development (45) & Mid-season (35) & Late (30) \\
\hline $\mathrm{K}_{C}$ & - & - & 0.5 & 1.15 & 1.15 & 0.6 \\
\hline Rooting depth(m) & - & - & 0.3 & - & 1.20 & - \\
\hline Critical depletion & - & - & 0.50 & - & 0.55 & 0.8 \\
\hline Yield response factor & - & - & 0.4 & 0.6 & 0.8 & 0.4 \\
\hline Crop height(m) & - & - & - & - & 1.0 & - \\
\hline Maize & - & - & Initial (45) & Development (45) & Mid-season (40) & Late (40) \\
\hline $\mathrm{K}_{C}$ & - & - & 0.5 & 1.2 & 1.2 & 0.6 \\
\hline Rooting depth(m) & - & - & 0.3 & - & 1.0 & - \\
\hline Critical depletion & - & - & 0.50 & - & 0.55 & 0.8 \\
\hline Yield response factor & - & - & 0.4 & 0.4 & 1.3 & 0.5 \\
\hline Crop height(m) & - & - & - & - & 2.0 & - \\
\hline
\end{tabular}

Table 2: TotalReference Evapotranspiration during different months for Pusa Region (2017-18)

\begin{tabular}{|c|c|c|c|c|c|c|c|}
\hline Month & $\begin{array}{l}\text { Min. } \operatorname{Temp}\left(^{0}\right. \\
\text { C) }\end{array}$ & $\begin{array}{l}\text { Max. Temp }\left(^{0}\right. \\
\text { C) }\end{array}$ & $\begin{array}{l}\text { Humidity } \\
(\%)\end{array}$ & $\begin{array}{l}\text { Wind speed } \\
(\mathrm{Km} / \mathrm{hr} .)\end{array}$ & $\begin{array}{l}\text { Sunshine } \\
\text { (hr.) }\end{array}$ & $\begin{array}{l}\operatorname{Rad}\left(\mathrm{MJ} / \mathrm{m}^{2}\right. \\
\text { /day) }\end{array}$ & $\begin{array}{l}\mathrm{ET}_{\mathrm{O}} \\
(\mathrm{mm} / \text { day })\end{array}$ \\
\hline January & 7.7 & 16.6 & 85 & 65 & 2.7 & 8.9 & 1.26 \\
\hline February & 11.9 & 26.0 & 78 & 70 & 6.4 & 14.9 & 2.34 \\
\hline March & 16.0 & 32.0 & 67 & 79 & 7.3 & 18.4 & 3.65 \\
\hline April & 21.6 & 34.2 & 65 & 138 & 6.2 & 18.5 & 4.65 \\
\hline May & 23.1 & 34.6 & 68 & 180 & 7.8 & 21.7 & 5.49 \\
\hline June & 26.3 & 35.2 & 71 & 173 & 7.2 & 20.9 & 5.45 \\
\hline July & 26.0 & 32.0 & 85 & 168 & 3.1 & 14.6 & 3.58 \\
\hline August & 26.2 & 33.7 & 77 & 163 & 7.2 & 20.2 & 4.90 \\
\hline $\begin{array}{l}\text { Septem- } \\
\text { ber }\end{array}$ & 25.0 & 31.4 & 86 & 127 & 3.2 & 13.1 & 3.09 \\
\hline October & 23.0 & 32.8 & 73 & 58 & 6.9 & 16.1 & 3.49 \\
\hline $\begin{array}{l}\text { Novem- } \\
\text { ber }\end{array}$ & 15.9 & 29.0 & 65 & 39 & 6.0 & 13.0 & 2.47 \\
\hline $\begin{array}{l}\text { Decem- } \\
\text { ber }\end{array}$ & 11.3 & 22.3 & 78 & 65 & 1.8 & 7.5 & 1.61 \\
\hline Average & 19.5 & 30.0 & 75 & 110 & 5.5 & 15.7 & 3.50 \\
\hline
\end{tabular}




\section{Crop water requirement of Rice}

Crop water requirement of rice was estimated using CROPWAT software. The crop parameters used for the estimation of the crop evapotranspiration, water balance calculations include crop coefficient $\left(\mathrm{K}_{C}\right)$, length of growing season, critical depletion level and yield response factor $\left(\mathrm{K}_{y}\right)$. Table 1 shows the adopted crop parameters for Rice crop for calculation of crop water requirement. The analysis revealed that the total crop water requirement for rice was $616.4 \mathrm{~mm}$ during the growth period of 150 days (Table 3 ).

Table 3: 3: Crop water requirement of Rice for kharif 2017

\begin{tabular}{llllll}
\hline Month & Decade & Stage & $\mathbf{K}_{\mathbf{C}}$ & $\mathbf{E T}_{\mathbf{C}} \mathbf{m m} / \mathbf{d a y}$ & $\mathbf{E T}_{\mathbf{C}} \mathbf{m m} / \mathbf{d e c}$ \\
Jun & 1 & Nurs & 1.20 & .67 & 6.0 \\
Jun & 2 & Nurs/Lpr & 1.08 & 5.48 & 54.8 \\
Jun & 3 & Nurs/Lpr & 1.06 & 5.28 & 52.8 \\
Jul & 1 & Init & 1.10 & 4.32 & 43.2 \\
Jul & 2 & Init & 1.10 & 3.50 & 35 \\
Jul & 3 & Deve & 1.10 & 4.14 & 45.6 \\
Aug & 1 & Deve & 1.11 & 5.25 & 52.5 \\
Aug & 2 & Deve & 1.12 & 5.93 & 59.3 \\
Aug & 3 & Mid & 1.12 & 5.12 & 56.3 \\
Sep & 1 & Mid & 1.12 & 3.99 & 39.9 \\
Sep & 2 & Mid & 1.12 & 3.24 & 32.4 \\
Sep & 3 & Late & 1.12 & 3.47 & 34.7 \\
Oct & 1 & Late & 1.09 & 3.74 & 37.4 \\
Oct & 2 & Late & 1.04 & 3.75 & 37.5 \\
Oct & 3 & Late & 1.00 & 3.21 & 28.6 \\
Total & & & & & 616.4 \\
\hline & & & & & \\
\hline
\end{tabular}

In the initial stage, rice only needs around $39.1 \mathrm{~mm}$ per decade to compensate for the water requirements of the cultivated plants (Table 3 ). The water requirement of rice increases linearly from $45.6 \mathrm{~mm}$ to $59.3 \mathrm{~mm}$ in the growth phase by the end of the decade. Then it drops from $39.9 \mathrm{~mm}$ to $32.4 \mathrm{~mm}$ at the beginning of the mid-season when the rice uses a lot of water to grow and reaches its maximum height; Finally, the water requirement of rice falls linearly from 34.7 to $28.6 \mathrm{~mm}$ at the end of the season, the ripening period. This is also the time to drain excess water for harvesting.

\section{Crop Water Requirement of Wheat}

The crop parameters used for the estimation of the crop evapotranspiration, water balance calculations include crop coefficient $\left(\mathrm{K}_{C}\right)$, length of growing season, critical depletion level and yield response factor $\left(\mathrm{K}_{y}\right)$. Table 1 shows the adopted crop parameters for wheat crop for calculation of crop water

Total Crop water requirement for wheat was $287.7 \mathrm{~mm}$. The maximum crop water requirement was found in month of March in $1^{\text {st }}$ decade and it is equal to 32.3 , and minimum water requirement of crop was in $1^{\text {st }}$ decade of November. requirement.

The total crop water requirement for wheat was $287.7 \mathrm{~mm}$ for study area (Table 4 ). In the initial phase, the water requirement was $38.4 \mathrm{~mm}$. In development stage (i.e. in December) the water requirement of wheat was $29.1 \mathrm{~mm}$. whereas in mid-season, water requirement increases from $10.8 \mathrm{~mm}$ to 25 $\mathrm{mm}$. In month of March, water requirement of wheat remains constant or we can say that it is similar to February month. It can be explained that the Wheat is growing to reach its maximum height. Finally, the demand for Wheat water begins to decrease linearly from $35.6 \mathrm{~mm}$ to $13.4 \mathrm{~mm}$ in late season. It is time to empty the water in the field for harvesting at the end of the late season stage. The data also shows that the need for irrigation is almost equal to the water requirements of crops in each decade since it is the dry season and there is no rain or very less rain. Thus, the Wheat uses mostly irrigated water.

\section{Crop Water Requirement of Rabi Maize}

The crop parameter of Rabi Maize has been shown through the Table 1 . The crop parameters used for the estimation of the crop evapotranspiration of rabi maize calculations 
Table 4: 4: Crop water requirement of Wheat for Rabi 2017-18

\begin{tabular}{llllll}
\hline Month & Decade & Stage & $\mathbf{K}_{\mathbf{C}}$ & $\mathbf{E T}_{\mathbf{C}} \mathbf{m m}$ /day & $\mathbf{E T}_{\mathbf{C}} \mathbf{m m} / \mathbf{d e c}$ \\
Nov & 1 & Init & 0.30 & 0.84 & 5.6 \\
Nov & 2 & Init & 0.30 & 0.74 & 12.4 \\
Nov & 3 & Init & 0.30 & 0.66 & 10.9 \\
Dec & 1 & Init & 0.30 & 0.57 & 9.5 \\
Dec & 2 & Deve & 0.41 & 0.65 & 8.3 \\
Dec & 3 & Deve & 0.65 & 0.97 & 10.5 \\
Jan & 1 & Deve & 0.90 & 1.17 & 10.3 \\
Jan & 2 & Mid & 1.10 & 1.27 & 10.8 \\
Jan & 3 & Mid & 1.13 & 1.73 & 18.3 \\
Feb & 1 & Mid & 1.13 & 2.20 & 22.3 \\
Feb & 2 & Mid & 1.13 & 2.60 & 26.3 \\
Feb & 3 & Mid & 1.13 & 3.08 & 25.0 \\
Mar & 1 & Late & 1.02 & 3.28 & 35.6 \\
Mar & 2 & Late & 0.78 & 2.83 & 34.8 \\
Mar & 3 & Late & 0.54 & 2.12 & 33.6 \\
Apr & 1 & Late & 0.35 & 1.50 & 13.4 \\
Total & & & & & 287.7 \\
\hline
\end{tabular}

includes crop coefficient $\left(\mathrm{K}_{C}\right)$, rooting depth, critical depletion level and yield response factor $\left(\mathrm{K}_{y}\right)$.

Crop water requirement of Rabi maize has been shown through the Table 5. The Rabi Maize evapotranspiration (Etc.) is equal to $375.3 \mathrm{~mm}$ during the growth period of 170 days. In the early stages, the rabi maize only needs about $10.3 \mathrm{~mm}$ per decade to compensate for the plants' water needs. The water

\section{Annual Crop water Requirement of Rice-Wheat and Rice-}

\section{Rabi Maize cropping system}

The crop water requirement of Rice- Wheat and Rice- Rabi Maize cropping system is shown through the Fig. 2. The analysis revealed that the crop water demand of Rice-Wheat cropping system is equal to $904.1 \mathrm{~mm}$ whereas the crop-water demand of Rice- Rabi Maize cropping system is equal to 991.7 mm. The Fig. 2 also shows that the crop water demand of Rice- Rabi Maize cropping system is more than the crop-water demand of Rice-Wheat cropping system by $87.6 \mathrm{~mm}$. This information can be used for preparing Block/ District irrigation planning of this region. requirement of rabi maize increases linearly from $8.1 \mathrm{~mm}$ to $18.3 \mathrm{~mm}$ at the end of the decade. $23.2 \mathrm{~mm}$ to $37.7 \mathrm{~mm}$ at the end of the mid-season, in which the Rabi Maize consumes a lot of water to grow and reaches its maximum height, finally the water requirement of the maize drops linearly from 41.7 $\mathrm{mm}$ to $29.3 \mathrm{~mm}$ at the end of the season, the ripening time.

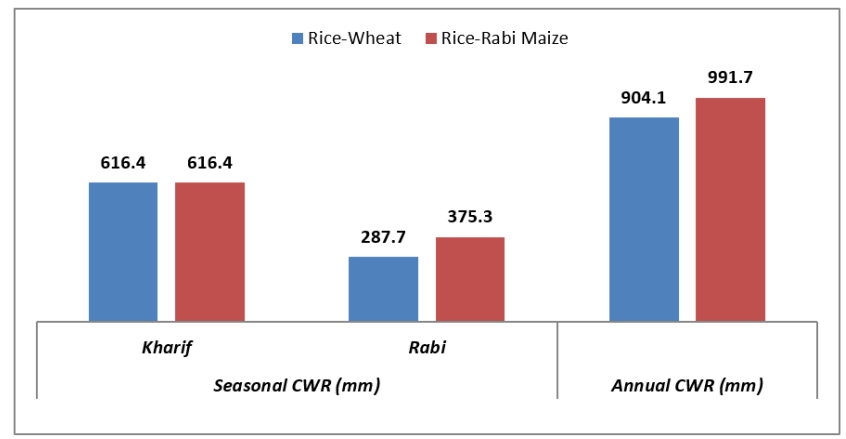

Fig. 2: Annual Crop Water Requirement of Rice -Wheat \&Rice -Rabi Maize cropping system for the year 2017-18

\section{CONCLUSIONS}

The crop water requirement of Rice-Rabi Maize cropping system is more as compared to Rice-Wheat cropping system. The study highlights the CROPWAT irrigation management 
Table 5: 5: Crop water requirement of Rabi Maize for 2017-18

\begin{tabular}{llllll}
\hline Month & Decade & Stage & $\mathbf{K}_{C}$ coeff & ET $_{\mathbf{C}} \mathbf{m m} /$ day & ET $_{\mathbf{C}} \mathbf{m m} / \mathbf{d e c}$ \\
Nov & 1 & Init & .50 & 1.41 & 8.4 \\
Nov & 2 & Init & .50 & 1.24 & 12.4 \\
Nov & 3 & Init & .50 & 1.09 & 10.9 \\
Dec & 1 & Init & .50 & .95 & 9.5 \\
Dec & 2 & Deve & .50 & .81 & 8.1 \\
Dec & 3 & Deve & .61 & .91 & 10.0 \\
Jan & 1 & Deve & .76 & 1.0 & 10.0 \\
Jan & 2 & Deve & .91 & 1.06 & 10.6 \\
Jan & 3 & Deve & 1.07 & 1.67 & 18.3 \\
Feb & 1 & Mid & 1.17 & 2.32 & 23.2 \\
Feb & 2 & Mid & 1.18 & 2.75 & 27.5 \\
Feb & 3 & Mid & 1.18 & 3.26 & 26.1 \\
Mar & 1 & Mid & 1.18 & 3.77 & 37.7 \\
Mar & 2 & Late & 1.14 & 4.17 & 41.7 \\
Mar & 3 & Late & 1.00 & 3.97 & 43.6 \\
Apr & 1 & Late & .84 & 3.63 & 36.3 \\
Apr & 2 & Late & .69 & 3.21 & 32.1 \\
Apr & 3 & Late & .59 & 2.93 & 29.3 \\
Total & & & & & 375.3 \\
\hline & & & & & \\
\hline
\end{tabular}

model could be used effectively and efficiently to estimate the agricultural crop water requirements and irrigation scheduling with different cropping patterns in North Bihar Condition. The crop water requirement of Rice in kharif 2017 was $616.4 \mathrm{~mm}$. Similarly, the crop water requirement of Wheat in Rabi 2017-2018 was $287.7 \mathrm{~mm}$ and the crop water requirement

\section{REFERENCES}

Ali MH. 2010. Crop Water Requirement and Irrigation Scheduling. Book. Fundamentals of Irrigation and On-farm Water Management 1:399-452.

Doorenbos J and Pruitt W 1977. Crop water requirements. FAO Irrigation and Drainage Paper No. 24. Food and Agric.Organiz.of the U.N. Rome.

Fao 2014. The state of Food and Agriculture, Food and Agricultural Organization of the United Nations (Rome) 978-92.

Jeet P, Patel N and Rajput TBS. 2016. On-Farm Balancing Reservoir Design on the Basis of Canal W ater A vailability and Gr ound W ater Quality. Journal of AgriSearch 3(1):26-31. url: https://dx. doi.org/10.21921/jas.v3i1.11404. doi: 10.21921/jas.v3i1.11404 of Rabi Maize in 2017-2018 was $375.3 \mathrm{~mm}$. The crop water requirement of Rice -Wheat and Rice-Rabi Maize cropping system were $904.1 \mathrm{~mm}$ and $991.7 \mathrm{~mm}$, respectively. These results can be used for preparing Block/ District irrigation planning of this region.

Kumar V, Jain CR and K S. 2018. Performance evaluation of AQUACROP Model for Rabi Maize crop in North Bihar condition. Journal of Pharmacognosy and Photochemistry 7(5):973-979.

Shah T, Singh OP and Mukherji A. 2006. Some aspects of South Asia's groundwater irrigation economy: analyses from a survey in India, Pakistan, Nepal Terai and Bangladesh. Hydrogeology Journal 14(3):286-309. url: https://dx.doi.org/10.1007/ s10040-005-0004-1. doi: 10.1007/s10040-005-0004-1

Smith M 1992. CROPWAT, FAO, Irrigation and Drainage paper-26, pp129.

Vk P and Choudhary MK. 2015. Crop water requirement estimated by using CROPWAT model: a case study of Halali dam command area. International Journal of Engineering and Management 5(3):553-557.

Citation:

Chandra R and Kumari S. 2021. Estimation of crop water requirement for rice- wheat and rice- maize cropping system using CROPWAT model for Pusa, Samastipur district, Bihar. Journal of AgriSearch 8(2): 143-148 